\title{
Production of sponge iron powder by reduction of rolling mill scale
}

\author{
M.I. Martín ${ }^{* 1}$, F.A. López ${ }^{* *}$, Jose M. Torralba ${ }^{* * *}$ \\ * University Carlos III de Madrid and IAAB, Avda. de la Universidad, 30, 28911 \\ Leganés, Madrid, Spain, e-mail: imartin@ietcc.csic.es \\ ** National Centre for Metallurgical Research (CENIM-CSIC), Avda. Gregorio del \\ Amo, 8, 28040 Madrid, Spain,e-mail:flopez@cenim.csic.es \\ *** Institute IMDEA Materials. University Carlos III de Madrid, Avda. de la \\ Universidad, 30, 28911 Leganés, Madrid, Spain,e-mail: torralba@ing.uc3m.es
}

${ }^{1}$ Corresponding author. Tel.: +34 9130204 40; fax: +34 913020700 .

E-mail addresses: imartin@ietcc.csic.es (M.I. Martín)

"Present address":

Dr. María Isabel Martín Hernández

Eduardo Torroja Institute for Construction Science (IETCC-CSIC).

Serrano Galvache, 4, 28033 Madrid, Spain 


\begin{abstract}
Rolling mill scale is a solid by-product of the steelmaking industry that contains metallic iron (Fe) and three types of iron oxides: wustite $(\mathrm{FeO})$, hematite $\left(\alpha-\mathrm{Fe}_{2} \mathrm{O}_{3}\right)$ and magnetite $\left(\mathrm{Fe}_{3} \mathrm{O}_{4}\right)$. It also contains traces of non-ferrous metals, alkaline compounds and oils from the rolling process. A study is made of the reduction of mill scale to sponge iron using coke at different temperatures and times. The reduced samples are studied by X-ray diffraction (XRD) and scanning electron microscopy (SEM). Oxygen analysis is carried out by combustion in a LECO oven. The reduction of mill scale allows the new use and development of this material to obtain sponge iron that can be re-used to the electric furnace as metallic load in steel manufacturing or as a raw material in the production of iron-base powder metallurgy parts.
\end{abstract}

Key words: Solid by-product; Rolling mill scale; Reduction; Coke; Sponge iron. 


\section{Introduction}

Mill scale is a steelmaking by-product from the rolling mill in the steel hot rolling process. Mill scale contains both iron in elemental form and three types of iron oxides: wustite $(\mathrm{FeO})$, hematite $\left(\alpha-\mathrm{Fe}_{2} \mathrm{O}_{3}\right)$ and magnetite $\left(\mathrm{Fe}_{3} \mathrm{O}_{4}\right)$. The chemical composition of mill scale varies according to the type of steel produced and the process used. The iron content is normally around $70 \%$, with traces of non-ferrous metals and alkaline compounds. Mill scale is contaminated with remains of lubricants and other oils and greases from the equipment associated with rolling operations. The oil content usually ranges between 0.1 and $2 \%$, but can reach up to $10 \%$. Mill scale is formed by flaky particles of a size of generally less than $5 \mathrm{~mm}$. The size distribution depends on the point in the process where the mill scale is generated. The smallest particles $\quad(<0.1$ $\mathrm{mm}$ ), known as mill scale sludge, are normally collected in the process water treatment units located close to the rolling machines. Depending on the process and the nature of the product, the weight of mill scale can vary between 20 and $50 \mathrm{~kg} / \mathrm{t}$ of hot rolled product. The average specific production of this by-product is typically around $35-40$ $\mathrm{kg} / \mathrm{t}$. In Spain some 44,000 tons of mill scale are generated each year ${ }^{1,2}$.

In view of its high metallic iron content and low non-ferrous metal and alkaline compound content, mill scale is suitable for direct recycling to the blast furnace via the sintering plant ${ }^{1,3}$. Approximately $90 \%$ of mill scale is directly recycled within the steelmaking industry and small amounts are used for ferroalloys, in cement plants and in the petrochemicals industry ${ }^{4-7}$. Coarse mill scale is practically $100 \%$ recycled via the sintering plant, while finer mill scale or mill scale sludge, which is more heavily contaminated with oils, ends up in landfills. Mill scale with a particle size of between 
0.5 and $5 \mathrm{~mm}$ and an oil content of less than $1.0 \%$ is considered returnable via sintering without any pretreatment. Mill scale with an oil content of more than $3.0 \%$ must be pretreated to avoid high volatile organic compound and dioxin emissions and problems in exhaust fume scrubbing systems. Mill scale sludge cannot be recycled via sintering since its fine particles contain a high oil level (5.0-20.0\%) and is normally treated as a landfill waste $e^{8,9}$.

The reduction of rolling mill scale to sponge iron powder is a new way to take advantage of a cheap by-product of the steelmaking industry, yielding sponge iron that can be re-used to the electric furnace as metallic charge for steelmaking to obtain a product with a lower residual content and improved properties ${ }^{8,10}$. Other possible uses include the manufacturing of structural components from sponge iron powder, magnets, components for electric motors, etc.

High purity sponge iron powder is currently manufactured from high purity iron ore following the basic steps of magnetic separation and milling, primary reduction process, hydrogen annealing, and final milling and classification.

Industrially, iron ore is placed with coal and lime in rotary furnaces at a rate that is controlled by the rotation speed. The interior of the furnace is coated with a refractory material. Carbon monoxide, produced by the effect of combustion, promotes the reduction of the iron ore. In order to control the temperature, fans are situated throughout the oven to provide the air necessary for combustion of the coal. The sponge iron obtained subsequently passes into a rotary cooler where it is cooled with water ${ }^{11-15}$.

There is another process, known as the "Höganäs process", in which high purity ore is placed together with coke and lime in ceramic containers which are in turn placed in a reduction furnace where the process takes place ${ }^{16}$. 
The Pyron Process ${ }^{17}$ describes a costly process for producing high iron purity by reduction of mill scale with hydrogen in a continuous conveyor which passes through a furnace at a temperature of about $1000{ }^{\circ} \mathrm{C}$. It also proposes to reduce mill scale by means of hydrogen in a fluidized bed reactor. Also explains a process using a solid reducing agent (graphite) in a furnace at $1000-1300{ }^{\circ} \mathrm{C}$ during the time necessary to carry out the reduction (10-14 hours). Once reduction is completed the sample is introduced into a closed steelcooling vessel. Previously purged with inert gas, e.g. nitrogen.

The proposed developed in this paper ${ }^{18}$ would produce considerable cost savings as it would eliminate the initial preparatory stages of existing methods, would shorten by $2 / 3$ the time taken for primary coke reduction, and the raw material would be a byproduct that is currently largely disposed of in landfills.

\section{Materials and methods}

The rolling mill scale used in this work was provided by an electric steelshop in northern Spain. This mill scale was from material would normally be sent to land fill. Prior to its chemical analysis the sample was dried at $80{ }^{\circ} \mathrm{C}$ for $24 \mathrm{~h}$. The mill scale presented an initial humidity of $5.0 \%$. The chemical composition of the rolling mill scale was determined by X-ray fluorescence (XRF) using a Philips model PW-404 wavelength dispersive $\mathrm{X}$-ray fluorescence emission spectrometer with $\mathrm{Rh}$ anode and generator voltage and current of $110 \mathrm{kV}$ and $80 \mathrm{~mA}$, respectively. The mill scale iron content, in terms of $\mathrm{Fe}_{\text {total }}$ and the various oxidation states $\left(\mathrm{Fe}^{3+}, \mathrm{Fe}^{2+}\right.$ and $\left.\mathrm{Fe}^{0}\right)$, was assessed with a $\mathrm{K}_{2} \mathrm{Cr}_{2} \mathrm{O}_{7} 0.1 \mathrm{~N}$ standard solution using a barium diphenylamine 
sulphonate $\left(\left(\mathrm{CH}_{12} \mathrm{H}_{10} \mathrm{NO}_{3} \mathrm{~S}\right)_{2} \mathrm{Ba}\right)$ indicator. For the determination of $\mathrm{Fe}^{2+}$ and $\mathrm{Fe}_{\text {total }}$ the mill scale sample was dissolved in a mixture of acids $\left(\mathrm{HNO}_{3}, \mathrm{HCl}\right.$ and $\left.\mathrm{HClO}_{4}\right)$. Metallic iron was determined after separation from $\mathrm{Fe}^{2+}$ and $\mathrm{Fe}^{3+}$ by dissolving the sample in a bromo-methanol solution for 1 hour with gentle stirring. The dissolved metallic iron was separated by filtration using $20 \mathrm{~mm}$ filter plate crucibles ${ }^{19}$.

The grain size distribution of the as-received mill scale was determined by passing the sample through screens of different sizes.

A Coulter model SA-3100 unit was used to determine the BET specific surface area $\left(\mathrm{S}_{\mathrm{BET}}\right)$. The $\mathrm{N}_{2}$ adsorption isotherm was assessed at $77 \mathrm{~K}$ in a mill scale sample previously degasified at $60{ }^{\circ} \mathrm{C}$ and $10^{-5}$ torr for 120 minutes, and the isotherm data was then used to determine the BET specific surface area value.

The mineralogical composition was determined by X-ray diffraction (XRD) using a Philips $\mathrm{X}^{\prime}$ Pert diffractometer with a $\mathrm{Cu}$ anode $\left(\mathrm{Cu} \mathrm{K}_{\alpha}\right.$ radiation) and a Ni filter to remove $\mathrm{K}_{\beta}$ radiation due to the sample's $\mathrm{Fe}$ content. The generator voltage and current were $40 \mathrm{kV}$ and $40 \mathrm{~mA}$, respectively.

The equivalent magnetite contained in the rolling mill scale was determined in a Sime model Forrer laboratory separator equipped with an IF-type electromagnet. The field intensity was 4900 Gs. Two previously prepared magnetite specimens were used as standards.

Coke was used to reduce the mill scale, employing different amounts of this reducing agent to achieve the reduction of the samples. The mill scale with coke was firstly subjected to conventional mixing in a turbula for 30 minutes, followed by high energy mechanical milling in a Pulverisette 6 planetary mill with a ball to load weight ratio of 10:1 at a speed of $400 \mathrm{rpm}$, in all cases using an Ar atmosphere, in 2 hour cycles 
of 1 hour milling and 1 hour rest. The balls used were $10 \mathrm{~mm}$ diameter stainless steel. The mill scale $(\mathrm{d}(0.5)=45 \mu \mathrm{m}$, after of milling) then underwent thermal treatment in an air atmosphere, in covered porcelain crucibles, in a CHESA brand muffle furnace using a mill scale/coke ratio of $100 / 50$ at various temperatures in the 1050 to $1150{ }^{\circ} \mathrm{C}$ range and for different reaction times (3, 6 and 12 hours). Calcium oxide (reagent grade) was used as fluxing agent. The final treatment of the samples was performed in an oven with a $\mathrm{H}_{2}$ atmosphere belonging to the company Höganäs $\mathrm{AB}$, at $900{ }^{\circ} \mathrm{C}$ for 0.5 hours with 1 hour of subsequent cooling in hydrogen.

Morphological analysis of the as-received and reduced mill scale samples was performed by scanning electron microscopy (SEM) using a Philips XL30 microscope equipped with back-scattered and secondary electron detectors and an EDAX brand "EDS" detector. The samples were prepared by depositing the mill scale on an adhesive tape and subsequently sputtered them with graphite.

Analysis of the samples for carbon and sulphur was performed by combustion with oxygen in a LECO model CS-244 induction oven, and for oxygen in a LECO model TC-436 induction oven, with subsequent detection by infra-red absorption.

The particle size distributions of the mill scale after of milling and the resulting sponge iron powder were carried out with a MALVERN Instruments Mastersizer 2000.

\section{Results and discussion}

\subsection{Characterisation of rolling mill scale}


Mill scale is a material with a lamellar morphology and a low specific surface area $\left(S_{\mathrm{BET}}=0.43 \mathrm{~m}^{2} / \mathrm{g}\right)$. It is comprised mainly of metallic iron and a mixture of the iron oxides wustite $(\mathrm{FeO})$, hematite $\left(\alpha-\mathrm{Fe}_{2} \mathrm{O}_{3}\right)$ and magnetite $\left(\mathrm{FeO} \cdot \mathrm{Fe}_{2} \mathrm{O}_{3}\right)$ (Fig. 1).

The chemical composition of the as-received mill scale is shown in Table 1 . The total iron content is $68.20 \%$. The analysed material also contains small amounts of other elements, such as $\mathrm{Mn}, \mathrm{Cu}, \mathrm{Si}, \mathrm{C}, \mathrm{Ca}, \mathrm{Ni}$, etc., along with approximately $2 \%$ of oils and greases from lubrication of the rolling machines. Table 2 shows the results of analysis of the different oxidation states of iron contained in the rolling mill scale, fundamentally $\mathrm{Fe}^{2+}$ and $\mathrm{Fe}^{3+}$ and a small part of metallic iron $(\mathrm{Fe})$.

The mill scale has a magnetic fraction of $38.06 \%$ in its composition (expressed as equivalent magnetite $-\mathrm{Fe}_{3} \mathrm{O}_{4}$ ).

The morphology of the mill scale powder is shown in Fig. 2 ( $a$ and b). As can be seen, it is preferentially lamellar with a heterogeneous surface formed basically by a matrix of iron oxides, as illustrated in (c). This figure clearly shows the presence of iron and oxygen as the major elements.

Table 3 indicates the grain size distribution of the mill scale, revealing that $70.7 \%$ of the accumulated weight presents a particle size of $\geq 0.125 \mathrm{~mm}$.

\subsection{Mill scale reduction tests}

\subsubsection{Reduction tests with coke}

Reduction of the iron oxides was achieved with coke by means of the "direct reduction" process [8] according to equation (1): 
$\mathrm{Fe}_{\mathrm{n}} \mathrm{O}_{\mathrm{m}}+\mathrm{mC} \rightarrow \mathrm{nFe}+\mathrm{mCO}$

Milled mill scale reduction experiments were carried out using using a mill scale/coke ratio of $100 / 50$, treatment temperatures of 1050,1100 and $1150{ }^{\circ} \mathrm{C}$, and three different reaction times (3, 6 and 12 hours). Fig. 3 shows X-ray diffraction spectra for the mill scale reduced with coke at $1100{ }^{\circ} \mathrm{C}$ for various reaction times. As can be seen, in the reductions carried out for 3 and 6 hours (a and b) the diffraction maxima corresponding to wustite $(\mathrm{FeO})$ disappear (according to the reaction $\mathrm{FeO}+\mathrm{C} \rightarrow$ $\mathrm{Fe}+\mathrm{CO}$ ), compared to the as-received mill scale composition (Fig. 1). The diffraction maxima for metallic iron $(\mathrm{Fe})$ increase with all three heat treatments, especially those performed for 3 and 6 hours. Therefore, the reduction of mill scale to sponge iron is favoured in the two treatments carried out for a shorter time in covered crucibles. Fig. 4 shows images of the rolling mill scale after the various thermal treatments and corresponding "EDS" analyses. These analyses confirm the existence of metallic iron in most zones of the mill scale samples reduced for 3 and 6 hours (some of these zones have been indicated in Fig. $4 \mathrm{a}$ and b) and the existence of areas with mainly oxygen and iron in the sample reduced for 12 hours (c).

XRD results for the reduction of mill scale with coke at 1050 and $1150{ }^{\circ} \mathrm{C}$ for reaction times of 3 and 12 hours are shown in Fig. 5. As can be seen, the diffraction maxima for metallic iron $(\mathrm{Fe})$ increase with all four thermal treatments while the maxima for wustite (FeO) disappear (according to reaction (1)) in the two treatments performed at $1050{ }^{\circ} \mathrm{C}$, compared to the as-received mill scale composition. In the treatments carried out at $1150{ }^{\circ} \mathrm{C}$ wustite continues to be present after 12 hours. Therefore it may be observed that the reaction time does not generally have any 
influence in the mill scale reduction process at $1050{ }^{\circ} \mathrm{C}$, but is influential in the treatments performed at higher temperatures (1150 and $1100{ }^{\circ} \mathrm{C}$ ) (Fig. 5 and 3, respectively), since in these processes small diffraction maxima appear for wustite after 12 hours, indicating that the mill scale may undergo a reoxidation process after long reaction times, due to the possible formation of carbon dioxide would act as an oxidant. Fig. 6 shows images of the rolling mill scale after thermal treatments performed at 1050 and $1150{ }^{\circ} \mathrm{C}$, along with the corresponding "EDS" analyses. Areas with different compositions can be observed for both treatments, with whiter and brighter areas corresponding to areas of metallic iron ("EDS" a1 and c2) and greyer areas corresponding to iron oxides ("EDS" b2 and c1). These SEM images confirm the XRD results shown in Fig. 5, where iron oxide phases $\left(\mathrm{Fe}_{\mathrm{n}} \mathrm{O}_{\mathrm{m}}\right)$ appeared in all cases next to metallic iron phases.

Table 4 shows the oxygen content of the mill scale samples as-received and after the reduction process with coke. It can be seen that the most favoured reduction process, with the lowest oxygen content after the thermal treatments with coke, is that performed at $1100{ }^{\circ} \mathrm{C}$. Of the three treatments carried out at this temperature, the most favoured is that performed for a reaction time of 6 hours, with a final oxygen content of $6.47 \%$.

\subsubsection{Final treatment in hydrogen atmosphere furnace}

The final treatment of the samples was carried out in a hydrogen atmosphere furnace at $900{ }^{\circ} \mathrm{C}$ for 0.5 hours, followed by 1 hour of cooling in hydrogen. Fig. 7 shows the X-ray diffraction spectrum of the mill scale treated at $1100{ }^{\circ} \mathrm{C}$ for 6 hours after thermal treatment in the $\mathrm{H}_{2}$ atmosphere furnace. Only diffraction maxima corresponding to 
metallic iron $(\mathrm{Fe})$ are observed, which confirms that in this case the reduction of the mill scale to sponge iron powder has been completed. Fig. 8 shows images of the sponge iron powder obtained after thermal treatment $(a, b)$ and the corresponding "EDS" analysis (c). The figure shows a powder with a spongy appearance, irregular but rounded, with a high specific surface area that makes it highly suitable for powder metallurgy applications. "EDS" analysis confirms that the sample is comprised only of metallic iron, thus achieving a sponge iron of great purity. The oxygen content in these samples was $0 \%$. The sponge iron powder particle size distribution is illustrated in Fig. 9, showing an average particle size of $157 \mu \mathrm{m}$. The obtained sponge iron can be used for produce powder metallurgy parts by pressing and sintering because it size distribution can assure a good flow behaviour.

The mill scale reduced at a temperature of $1100{ }^{\circ} \mathrm{C}$ for a reaction time of 3 hours has been treated identically, yielding similar test results.

\section{Conclusions}

Sponge iron powder has been obtained by reducing rolling mill scale with coke via thermal treatment in covered crucibles in an air atmosphere furnace and subsequent final treatment in a hydrogen atmosphere furnace.

The most effective thermal treatments in the air atmosphere furnace have been those performed at a temperature of $1100{ }^{\circ} \mathrm{C}$ for reaction times of 3 and 6 hours, which yielded the lowest oxygen contents in the treated samples.

The proposed mill scale reduction process allows the obtainment of a sponge iron powder of an irregular morphology with an average particle size of $157 \mu \mathrm{m}$ and 
great purity, making use of a cheap by-product of the steelmaking industry which is currently largely disposed of in landfills.

The iron powder obtained may be used in conventional steelmaking processes or as a raw material in powder metallurgy processes.

\section{Acknowledgments}

The authors are grateful to Ministry for Education and Science of Spain (MEC) for financial support of the Dr. M.I. Martín through a "Juan de la Cierva" programme contract (JCI-2005-1892-13) and to Per-Olof Larsson of Höganäs AB for technical assistance with the hydrogen atmosphere furnace.

\section{References}

[1] International Iron and Steel Institute: The Management of Steel Industry Byproducts and Waste, Committee on Environmental Affairs, Brussels, 1987, chapter 6.

[2] International Iron and Steel Institute: The Management of Steel Plant Ferruginous By-Products, Committee on Environmental Affairs and Committee on Technology, Brussels, 1994, chapters 6, 7.

[3] A.M. Fleischanderl: Managing Steel Mill Wastes \& By-products: Crisis and Opportunity, Gorham/Intertech's 13th International Iron and Steel Development Forum, Antwerp, Belgium, 1998.

[4] Cho Young-Ki: Making method for ferrite used mill/scales, Patent KR 9103783, June 1991. 
[5] D. Osing: Reuse of metallurgical fines, Patent WO 96/31630, 1996.

[6] A. Fleischanderl, J. Pesl and W. Gerbert. Aspect of recycling of steelworks byproducts through the BOF, SEAISI Quarterly, 1999, 28(2), 51-60.

[7] A. Poulalion: Process of recycling mill scale of alloyed steel in an electric furnace into a ferro-silicon product, Patent EP 1122319, 2001.

[8] L. Camci, S. Aydin, C. Arslan: Reduction of ion oxides in solid wastes generated by steelworks, Turkish J. Eng. Env. Sci., 2002, 26, 37-44.

[9] European Commission: Reference Document on Best Available Techniques in the Ferrous Metals Processing Industries, IPPC Directive European Commission, Institute for Prospective Technological Studies, Directorate-General Joint Research Centre, 161162, 2001, Seville, Spain.

[10] J.-W. Park, J.-C. Ahn, H. Song, K. Park, H. Shin, J.-S. Ahn: Reduction characteristics of oily hot rolling mill sludge by direct reduced iron method, Conserv. Recy., 2002, 34(2), 129-140.

[11] C.A. Mann: Method of making sponge iron powder, Patent US 2,237,867, 1941.

[12] F.W. de Jahn: Method of prodution sponge iron, Patent US 2,668,105, 1954.

[13] J.R. Wood, G.A. Pickin, D.S. Harvey: Production of sponge iron, Patent US 4,199,349, 1980 .

[14] S. Uenosomo, A. Sonobe, H. Suhihara: Method for production sponge iron and reduced iron power and method for production thereof, Patent US 6,918,945 B2, 2005. [15] Y. Suzuki, A. Sonobe, T. Koroki, Y. Sakaguchi, H. Itaya, Y. Misumi, I. Futnasu: Process for production sponge iron and reduced iron powder sponge iron and charging apparatus, Patent US 2005/0193862, 2005. 
[16] J.M. Palacios, J.L. Arana, J.I. Larburu, L. Iniesta, La Fabricación del Acero, UNESID, 1998, Madrid, España.

[17] Viramontes-Brown, Ricardo; Berrun-Castanon, Jorge D.: Process and apparatus for producing high purity iron, Patent US 4,747,872 A, 1998.

[18] J.M. Torralba, M.I. Martín, F.A. López y M.E. Rabanal: Procedimiento de obtención de esponjas metálicas, Patente ES 2342815 B1, 2010.

[19] M.I. Martín: Aplicación tecnológica de un residuo de la industria del acero en la eliminación de metales contaminantes, $\mathrm{PhD}$ Thesis, Universidad Complutense de Madrid, Madrid, Spain, 2004. 
Table 1. Chemical composition of the rolling mill scale

\begin{tabular}{|c|c|}
\hline Element & Weight (\%) \\
\hline $\mathrm{Fe}$ & 68.20 \\
\hline Mn & 0.48 \\
\hline $\mathrm{Cu}$ & 0.47 \\
\hline $\mathrm{Si}$ & 0.25 \\
\hline $\mathrm{Ca}$ & 0.13 \\
\hline $\mathrm{Ni}$ & 0.11 \\
\hline $\mathrm{Cr}$ & 0.07 \\
\hline $\mathrm{Mg}$ & 0.05 \\
\hline $\mathrm{Hf}$ & 0.04 \\
\hline Ho & 0.04 \\
\hline $\mathrm{Zn}$ & 0.03 \\
\hline $\mathrm{Co}$ & 0.03 \\
\hline As & 0.03 \\
\hline $\mathrm{Ir}$ & 0.03 \\
\hline $\mathrm{Sn}$ & 0.03 \\
\hline $\mathrm{P}$ & 0.02 \\
\hline $\mathrm{Ga}$ & 0.02 \\
\hline $\mathrm{Pt}$ & 0.02 \\
\hline Stotal & 0.04 \\
\hline Ctotal & 0.21 \\
\hline
\end{tabular}


Table 2. Analysis of the iron contained in the mill scale

State of oxidation

\begin{tabular}{lc}
\hline $\mathrm{Fe}^{2+}$ & 48.70 \\
$\mathrm{Fe}^{3+}$ & 12.41 \\
$\mathrm{Fe}^{0}$ & 7.09 \\
\hline
\end{tabular}

Weight (\%) 
Table 3. Particle size distribution of the mill scale

\begin{tabular}{ccc}
\hline Particle size (mm) & Weight $(\%)$ & Accumulated weight $(\%)$ \\
\hline$>2.380$ & 2.1 & 2.1 \\
$2.380-1.167$ & 3.7 & 5.8 \\
$1.168-0.49$ & 9.1 & 14.9 \\
$0.50-0.249$ & 20.6 & 35.4 \\
$0.250-0.125$ & 35.3 & 70.7 \\
$<0.125$ & 29.2 & 99.9 \\
\hline
\end{tabular}


Table 4. Oxygen content

\section{Reduction treatment}

$\% \mathrm{O}(\mathrm{w} / \mathrm{w})$

(Temperature / time)

\begin{tabular}{rc} 
Rolling mill scale & 20.85 \\
$1050^{\circ} \mathrm{C} / 3 \mathrm{~h}$ & 12.08 \\
$1050^{\circ} \mathrm{C} / 6 \mathrm{~h}$ & 10.20 \\
$1050{ }^{\circ} \mathrm{C} / 12 \mathrm{~h}$ & 13.91 \\
$1100{ }^{\circ} \mathrm{C} / 3 \mathrm{~h}$ & 8.53 \\
$1100^{\circ} \mathrm{C} / 6 \mathrm{~h}$ & 6.47 \\
$1100{ }^{\circ} \mathrm{C} / 12 \mathrm{~h}$ & 10.17 \\
$1150^{\circ} \mathrm{C} / 3 \mathrm{~h}$ & 14.90 \\
$1150^{\circ} \mathrm{C} / 6 \mathrm{~h}$ & 12.90 \\
$1150^{\circ} \mathrm{C} / 12 \mathrm{~h}$ & 15.45 \\
\hline
\end{tabular}




\section{FIGURE CAPTIONS}

Fig. 1. X-ray diffraction patterns for the rolling mill scale.

Fig. 2. Secondary electron images of the mill scale, (a) 200x, (b) 500x and the corresponding "EDS” analysis (c).

Fig. 3. X-ray diffraction patterns for the reduced mill scale by coke. Mill scale/coke ratio $=100 / 50$, temperature $=1100{ }^{\circ} \mathrm{C}$, (a) time $=3 \mathrm{~h}$, (b) time $=6 \mathrm{~h}$, (c) time $=12 \mathrm{~h}$.

Fig. 4. Secondary electron images of the reduced mill scale and "EDS" analysis. Mill scale $/$ coke ratio $=100 / 50$, temperature $=1100^{\circ} \mathrm{C}$. (a) time $=3 \mathrm{~h}$, (b) time $=6 \mathrm{~h}$, (c) time $=12 \mathrm{~h}$.

Fig. 5. X-ray diffraction patterns for the reduced mill scale by coke, (a) time $=3 \mathrm{~h}$, (b) time $=12 \mathrm{~h}$, temperature $=1050{ }^{\circ} \mathrm{C} ;(\mathrm{c})$ time $=3 \mathrm{~h},(\mathrm{~d})$ time $=12 \mathrm{~h}$, temperature $=1150$ ${ }^{\circ} \mathrm{C}$. Mill scale/coke ratio $=100 / 50$.

Fig. 6. Backscattered electron images of the reduced mill scale and "EDS" analysis (a) time $=3 \mathrm{~h}$, (b) time $=12 \mathrm{~h}$, temperature $=1050^{\circ} \mathrm{C} ;(\mathrm{c})$ time $=3 \mathrm{~h}$, temperature $=1150$ ${ }^{\circ} \mathrm{C}$. Mill scale/coke ratio $=100 / 50 .(*)$ Carbon.

Fig. 7. X-ray diffraction patterns for the reduced mill scale $\left(1100^{\circ} \mathrm{C} / 6 \mathrm{~h}\right)$ after of treatment in hydrogen furnace $\left(\mathrm{T}=900{ }^{\circ} \mathrm{C} / 0.5 \mathrm{~h}+\right.$ cooling: 1 hour in hydrogen $)$. 
Fig. 8. Secondary electron images of the reduced mill scale $\left(1100{ }^{\circ} \mathrm{C} / 6 \mathrm{~h}\right)$ after of treatment in hydrogen furnace (a, b) and "EDS" analysis (c). T $=900{ }^{\circ} \mathrm{C} / 0.5 \mathrm{~h}+$ cooling: 1 hour in hydrogen.

Fig. 9. Particle size distribution of obtained sponge iron. 


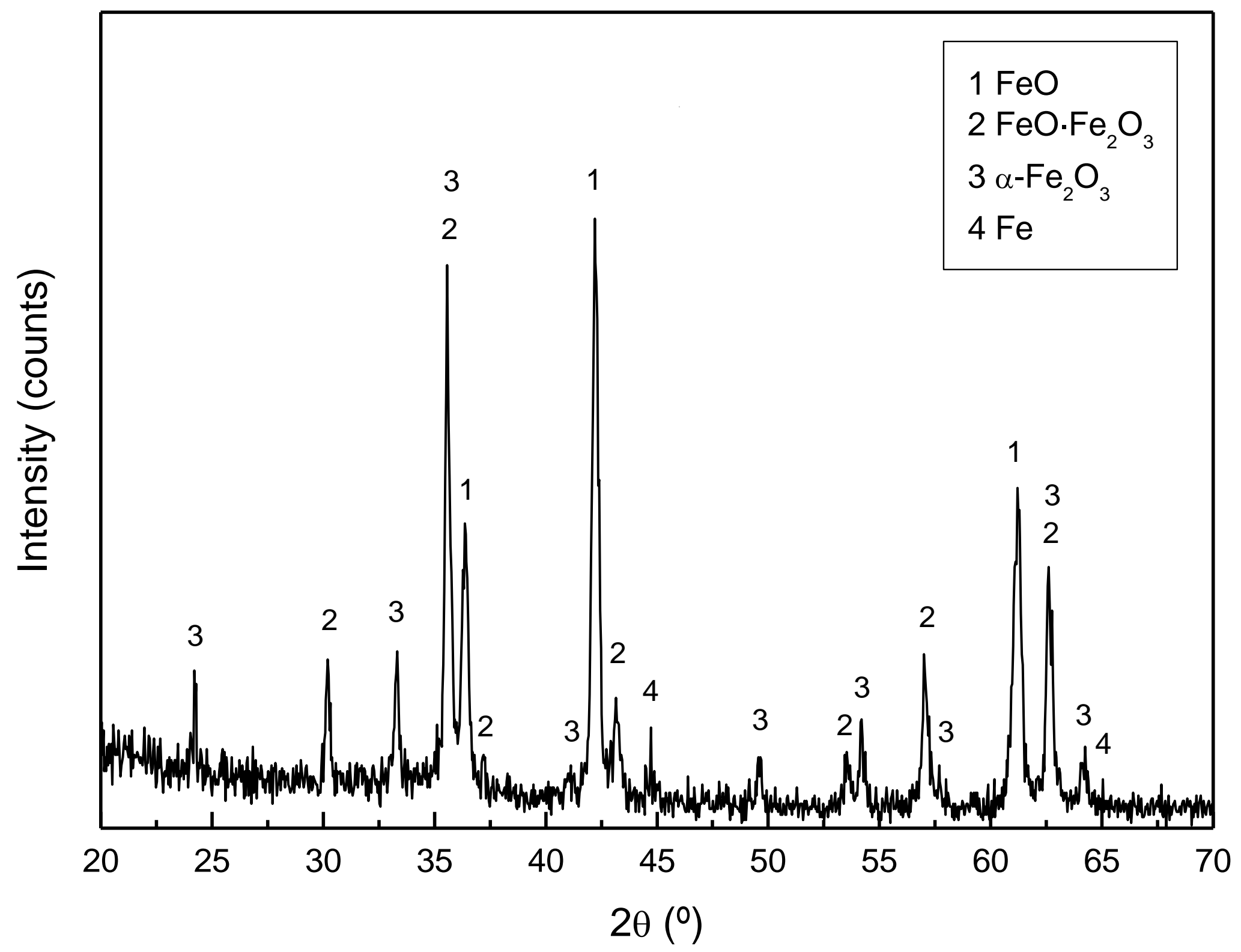



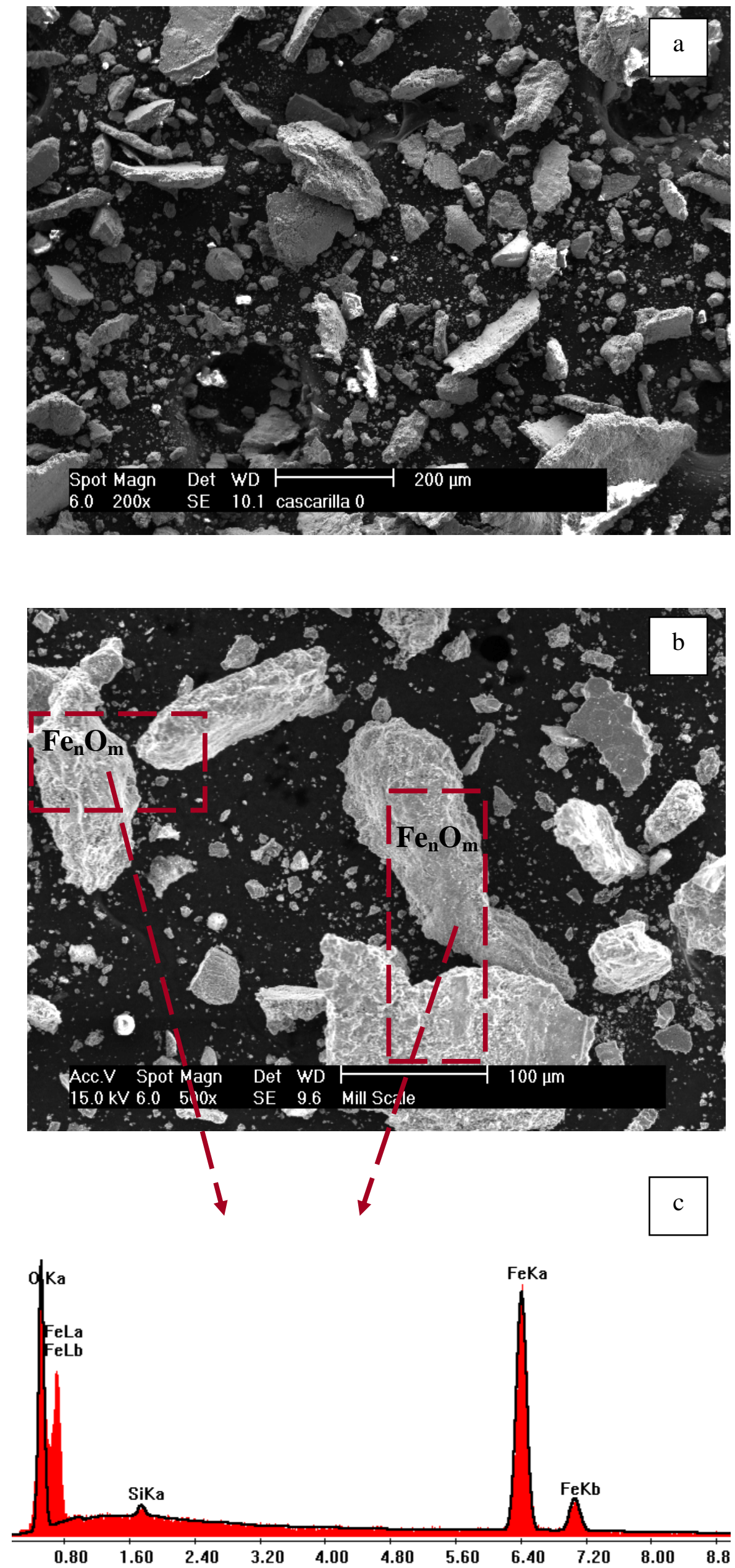

Energy (keV) 

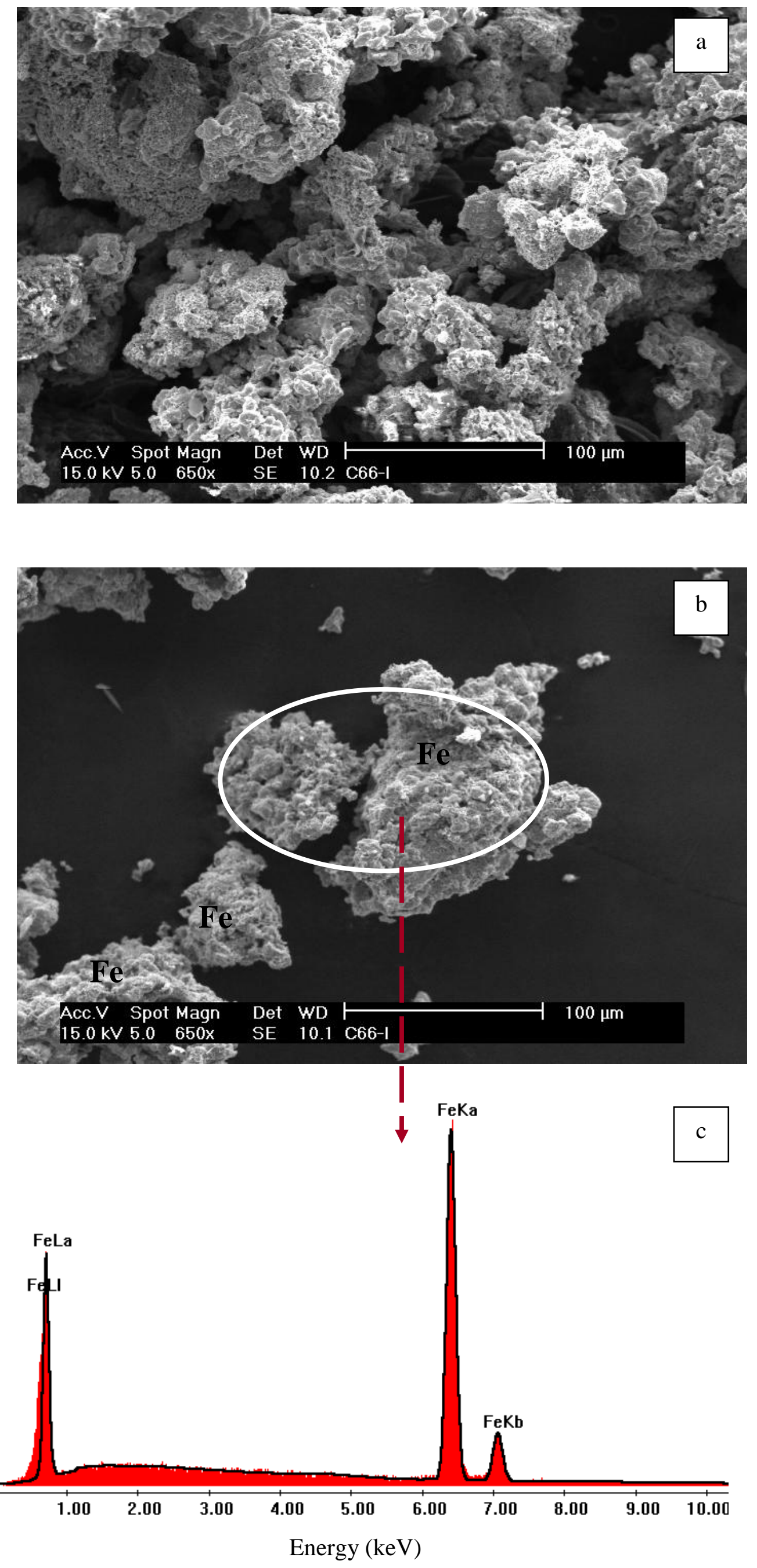


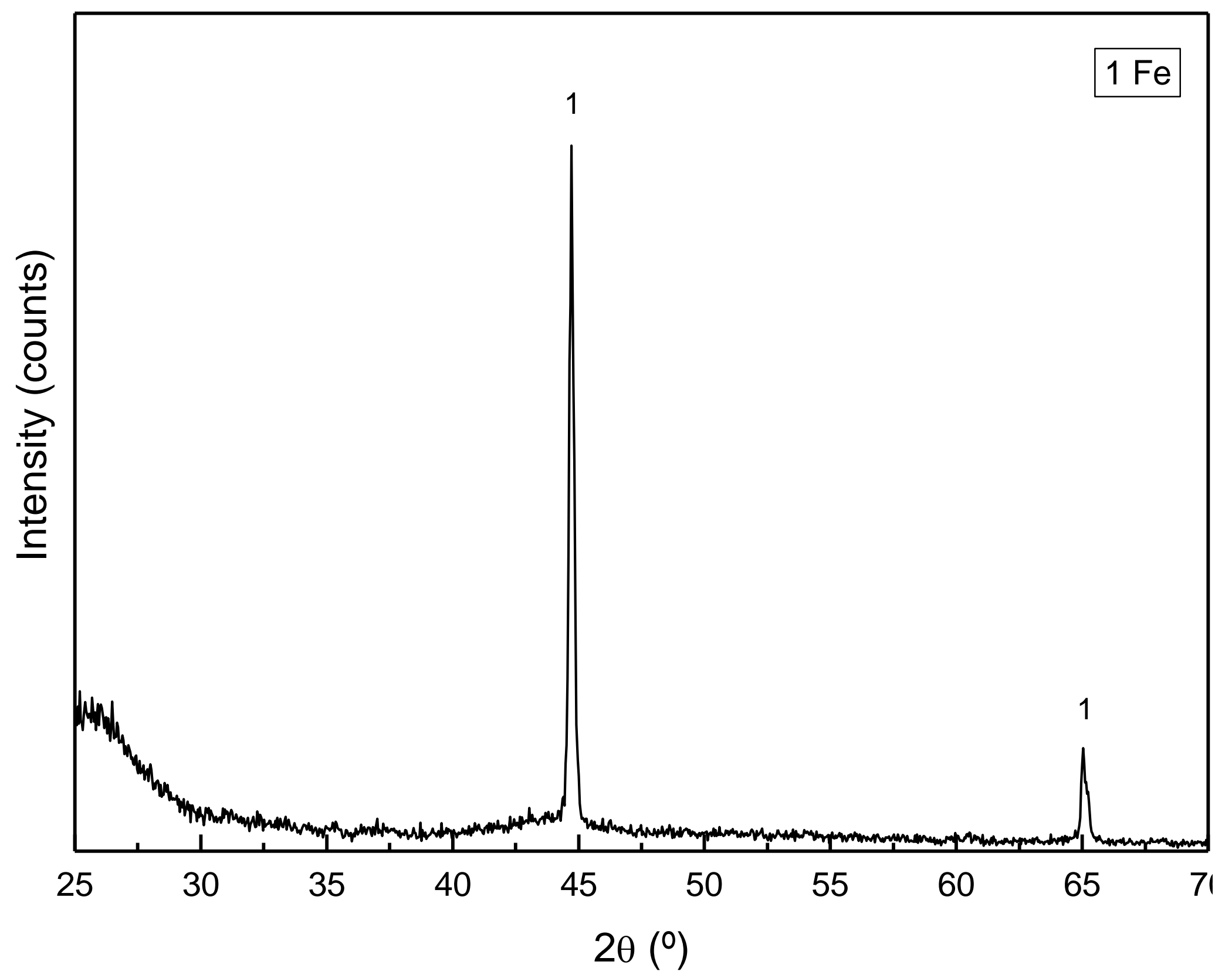



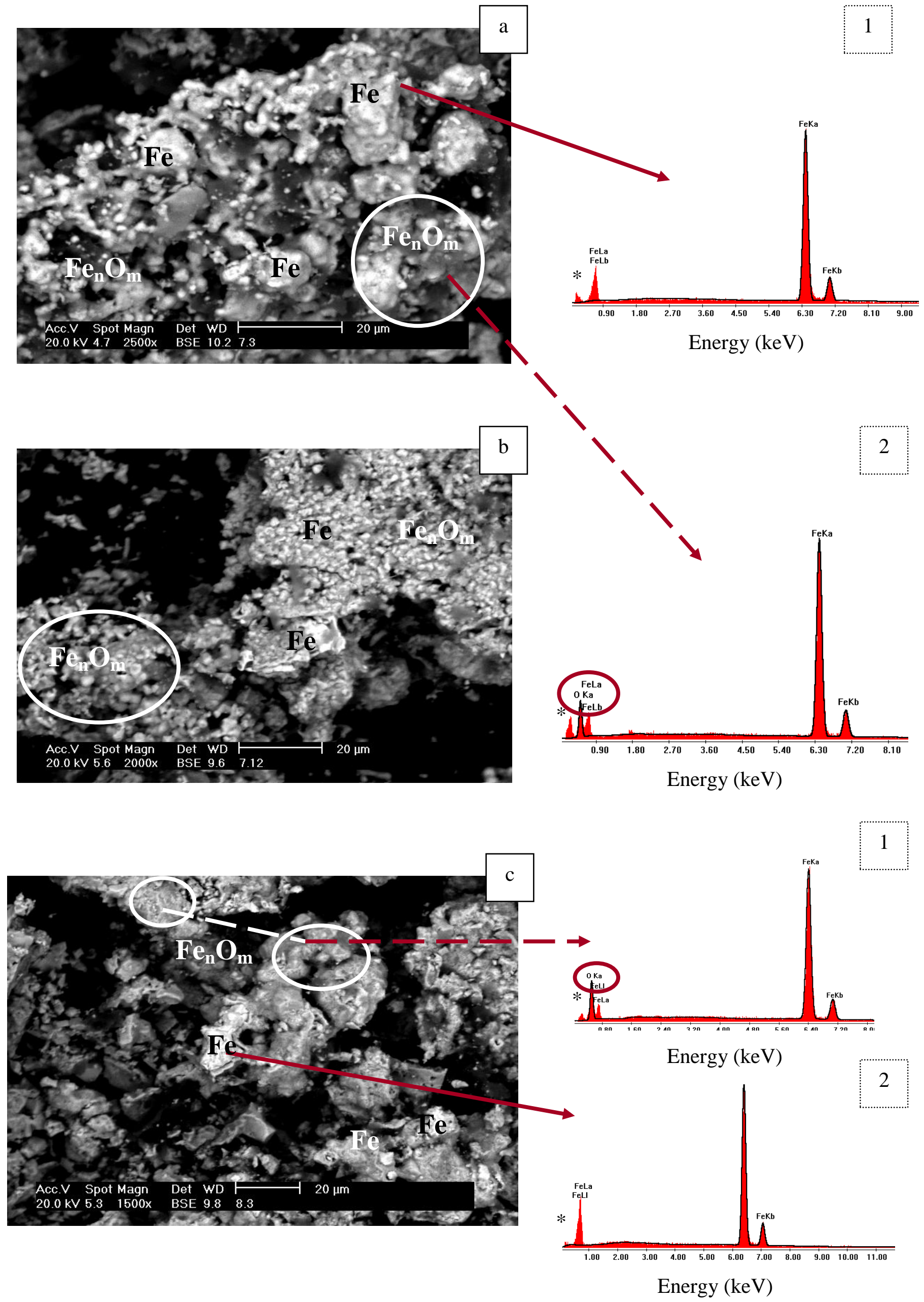

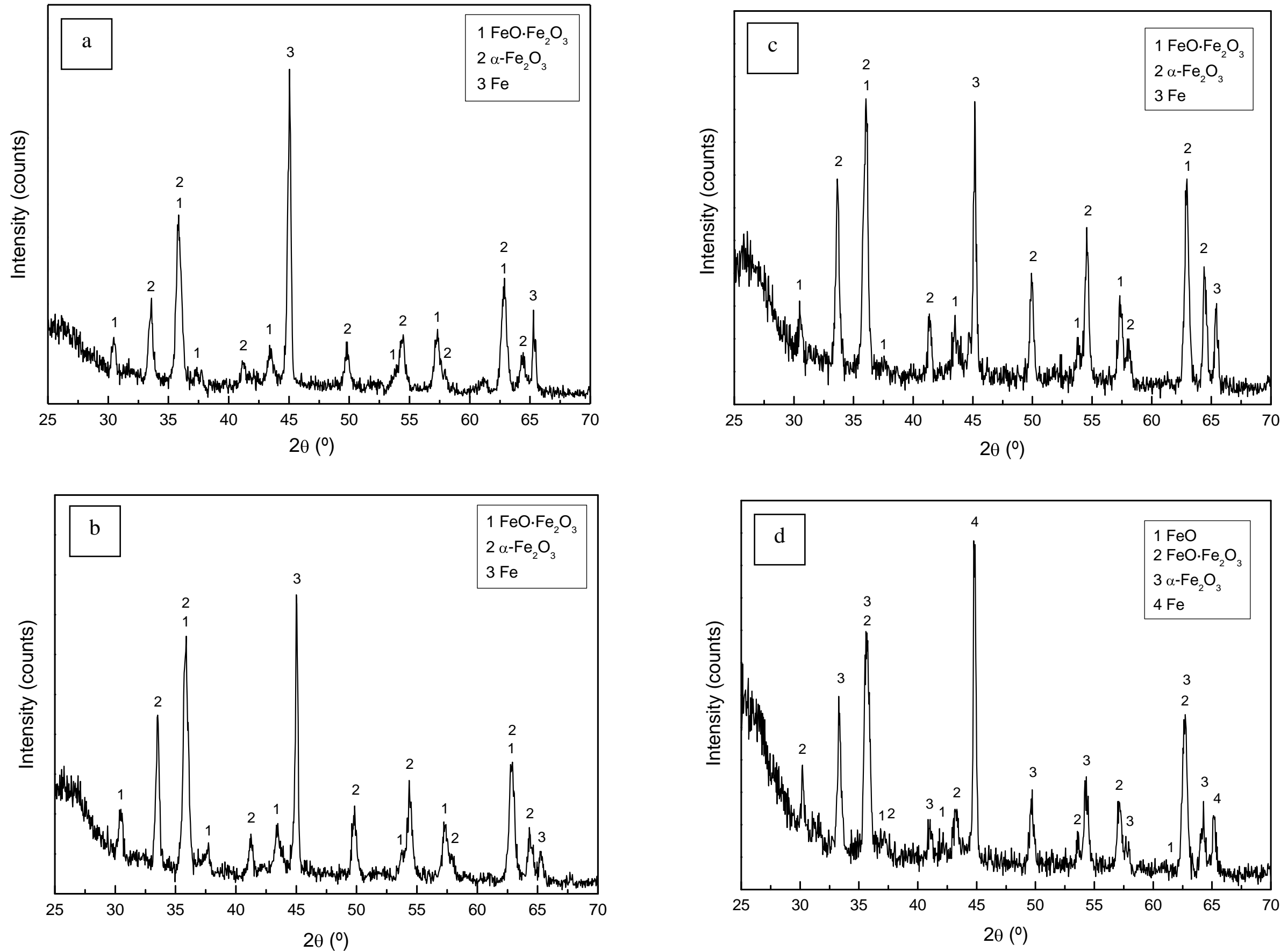

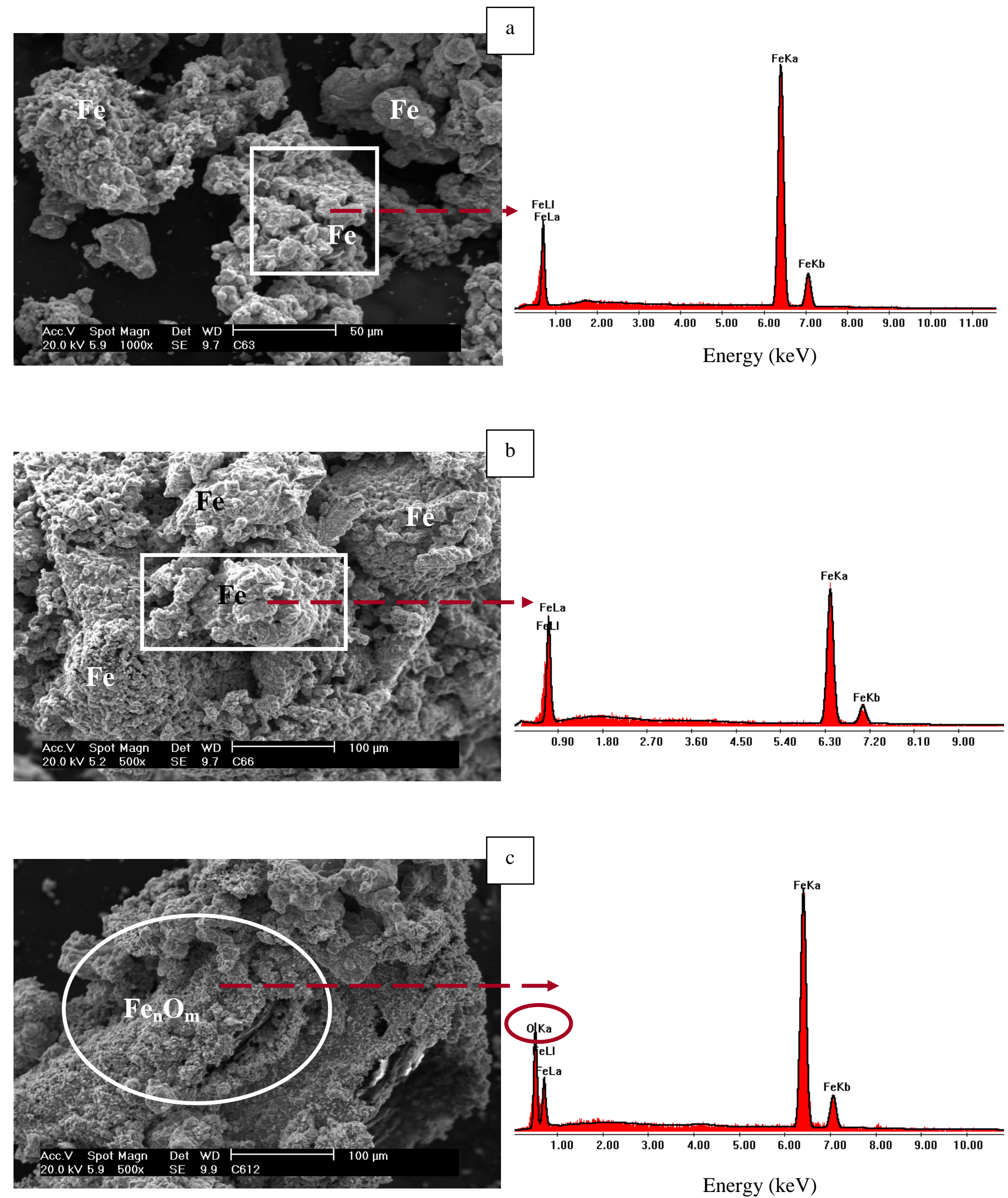

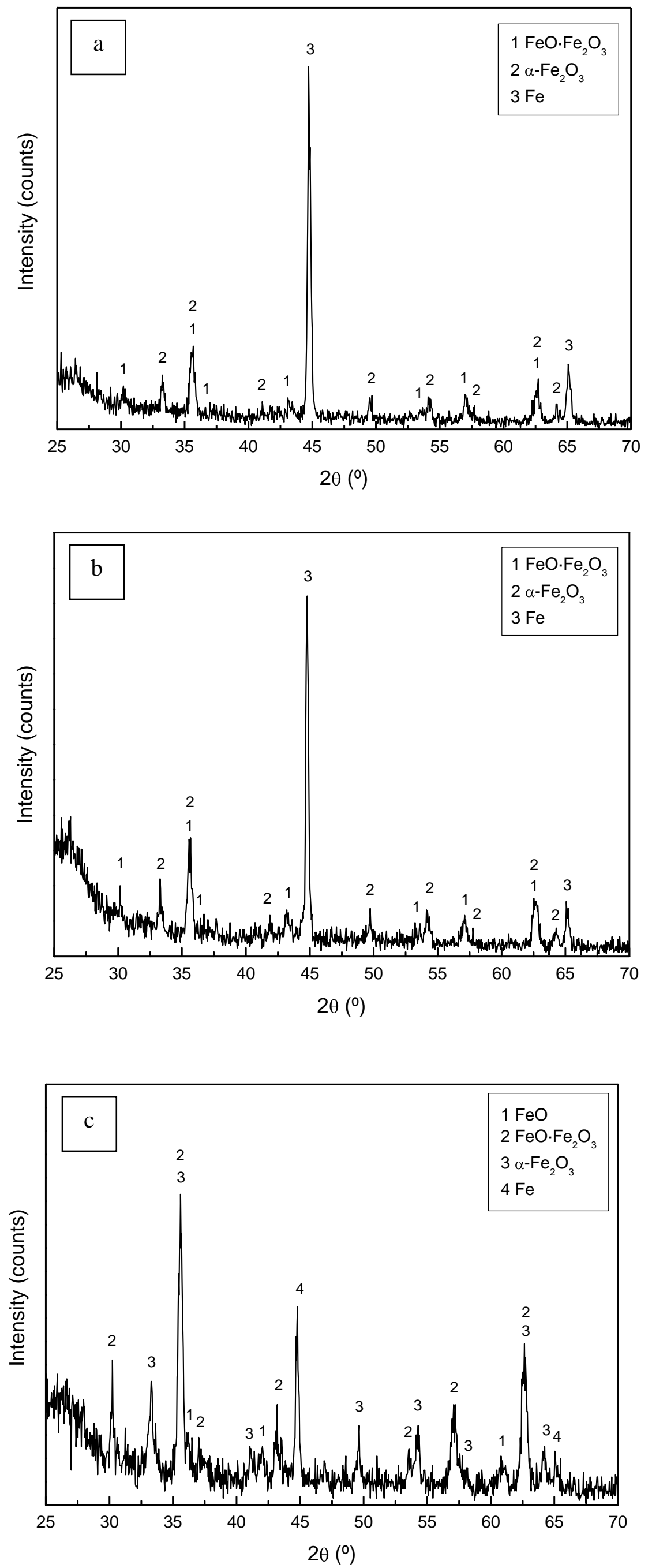


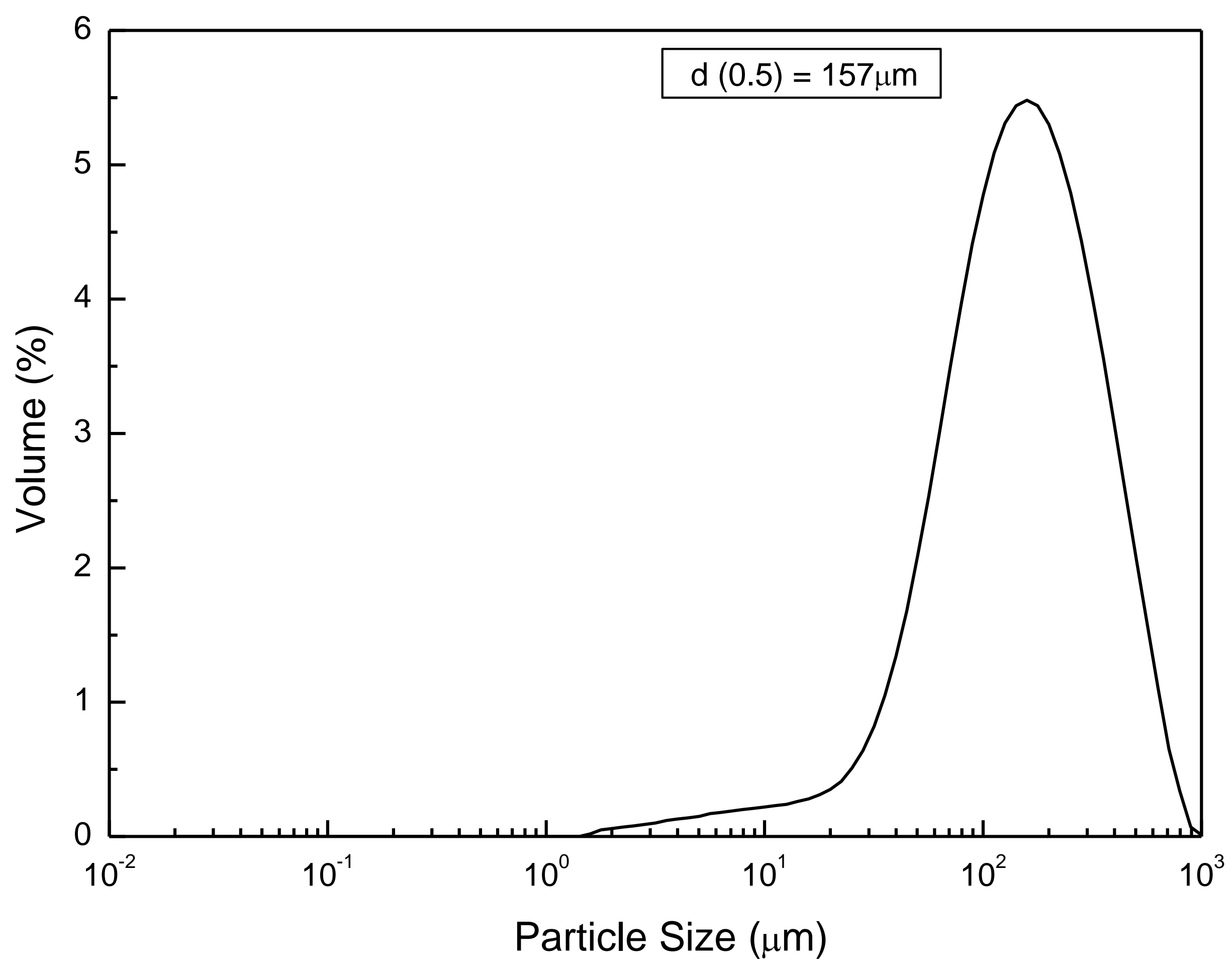

